\title{
Cuando el vino impregnó la isla de Mallorca: el comercio púnico-ebusitano y las comunidades locales durante la segunda mitad del siglo $\mathrm{V}$ y el siglo IV a.C.
}

\author{
When wine slowly impregnated the island of Majorca: Punic-Ebusitan trade and local \\ communities between 450 and $300 \mathrm{BC}$
}

\author{
Jordi Hernández-Gasch (*) \\ Carlos Quintana (**)
}

\section{RESUMEN}

En este artículo se discuten los conceptos colonialismo y colonización en relación a las Islas Baleares para concluir que es del todo inapropiado seguir refiriéndose al último. Se analizan datos procedentes de excavaciones y prospecciones arqueológicas, algunos inéditos hasta la fecha, desde un punto de vista cuantitativo y cualitativo. Estos datos muestran que las dinámicas iniciadas en el siglo VI a.C. continuaron en los siglos siguientes sin apenas cambios, aunque en el siglo IV, se produjo un incremento en la llegada de productos foráneos, desde un punto de vista cuantitativo y, en cierta medida, cualitativo también. La vajilla de lujo permaneció ligada a los asentamientos costeros, estableciéndose una diferencia diacrítica entre las comunidades ligadas a los comerciantes púnicos y las del interior. Se exploran también los mecanismos de intercambio entre diferentes actores y las posibles rutas seguidas. Las guerras cartaginesas y la necesidad de mercenarios fueron esencialmente responsables de este intercambio.
(*) Grup de Recerca d'Arqueologia Social Mediterrània, Departament de Prehistòria, Universitat Autònoma de Barcelona 08193 Bellaterra, Barcelona, España.

Correo e.: jhernandezgasch@gmail.com

(**) Grup de Recerca Arqueouib, Departament de Ciències Històriques i Teoria de les Arts, Facultat de Filosofia i Lletres, Universitat de les Illes Balears. Carretera de Valldemossa km 7,5. 07122 Palma de Mallorca - Illes Balears. España.

Correo-e.: quintanacar@gmail.com

Recibido 22-V-2012; aceptado 2-VIII-2012.

\begin{abstract}
In this paper the concepts of colonialism and colonization applied to the Balearic Islands are discussed, concluding that their use is totally inappropriate. Published and unpublished data from archaeological excavations and surveys, are analyzed from both a quantitative and qualitative perspective. They show that some dynamics started in the $6^{\text {th }}$ century $B C$ and continued during the following centuries essentially with no changes, although during the $4^{\text {th }}$ century an increase can be detected from a quantitative and somehow qualitative point of view in the arrival of foreign goods. Luxury ceramics remained attached to the coastal settlements establishing a diacritical difference between communities tied up to Punic traders and those inland. Mechanisms of exchange between different actors and feasible routes of trade are explored. The Carthaginian wars and the need for mercenaries were basically responsible for such a trade.
\end{abstract}

Palabras clave: Colonialismo; Colonización; Comercio; Cambio social; Mediterráneo occidental; Segunda Edad del Hierro; Islas Baleares; Eivissa/Ibiza/YBŜM/Ebusus; Ánforas; Vajilla fina; Mercenarios.

Key words: Colonialism; Colonization; Trade; Social change; Western Mediterranean; Second Iron Age; Balearic Islands; Eivissa/Ibiza/YBŜSM/Ebusus; Amphorae; Fine wares; Mercenaries.

\section{PROPÓSITO, MATERIALES Y METODOLOGÍA}

Este artículo es fruto de una investigación que tiene como origen y motor una sospecha creciente 
entre los arqueólogos que tratan la Protohistoria de las Islas Baleares (1) (Fig. 1): el concepto "colonización", referido a la incidencia púnico-ebusitana sobre la sociedad autóctona de Mallorca es inadecuado, no solo en base a los datos disponibles, sino también desde un punto de vista teórico (2). El concepto fue usado por vez primera en los años 1980, en una de las muchas periodizaciones propuestas para la prehistoria balear (Mayoral 1984), así como en las publicaciones a partir de la excavación de la base ebusitana del islote de $\mathrm{Na}$ Guardis, ubicado en la costa sur de Mallorca (Guerrero 1984a, 1984b, 1997). Posteriormente, fue adoptado más o menos implícitamente por varios autores (Vallespir et al. 1987; Coll 1989: 53; Cardell et al. 1994: 56-57; Quintana y Guerrero 2004).

En las últimas décadas se propuso un modelo de intercambio aristocrático, que operaría desde el siglo IX a.C. hasta el siglo V a.C. Alrededor del siglo IV a.C., este comercio se transformaría en un modelo empórico o maqom (Guerrero 2004).

En el actual estado de la investigación, hay que dar un paso atrás y plantearnos si es posible de-

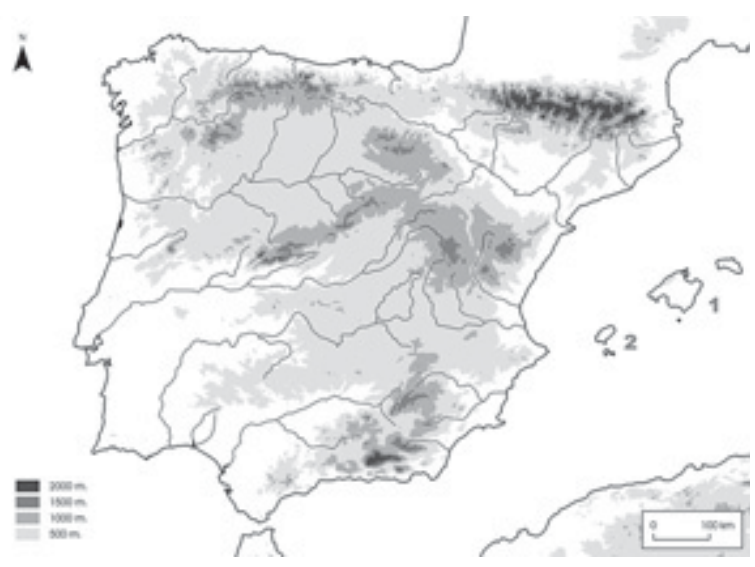

Fig. 1. Mapa de la Península Ibérica y las Islas Baleares. (1) Mallorca, (2) Eivissa.

(1) El término "Islas Baleares" se usa en este trabajo en su sentido histórico y geográfico, no en el administrativo que tiene hoy en día. Por ello, se refiere a las islas de Mallorca y Menorca, mientras que Ibiza/Eivissa y Formentera pertenecen al archipiélago pitiuso.

(2) García Rosselló, J. 2010: Análisis traceológico de la cerámica. Modelado y espacio social durante el postalayótico (siglo V-I a.C.) en la península de Santa Ponça (Calvià, Mallorca). Tesis doctoral inédita, Universitat de les Illes Balears. tectar tal cambio de modelo en las Islas Baleares. Además, se necesita redefinir las relaciones entre los elementos ebusitanos y el mundo autóctono balear.

En estas páginas nos basamos en el análisis de la cultura material mueble, con las limitaciones que se expondrán más adelante. Elementos, como la arquitectura o las manifestaciones rituales, han quedado fuera del estudio, ya que son más inferencias de los investigadores que evidencias por sí mismas.

Los ítems arqueológicos tratados son las cerámicas de importación y, en concreto, las ánforas y la vajilla fina. Excluimos los metales por su larga perdurabilidad y, a veces, origen incierto. Por ejemplo, las figuras y la vajilla metálica podrían haberse desechado siglos después de su fabricación o haber sido introducidas en la isla mucho después de su manufactura (3). La exclusión de la cerámica común se debe a que, al menos en el actual estado de conocimientos, sus producciones suelen tener una baja resolución cronológica que impide la adscripción inequívoca a un cierto período. Lo mismo puede decirse de las cuentas de pasta vítrea.

Restricciones similares operan con respecto a las ánforas. Los contenedores de origen ibérico deben dejarse de lado y considerar solo los ebusitanos (tipos 1.3.2.3. y 8.1.1.1.) (Fig. 2) y los griegos (en concreto, masaliotas y corintios). Ramon (1991: 134) concluyó que su contenido probable era el vino en base a las trazas de resina detectadas en algunos tipos ebusitanos. Abunda en ello que Diodoro de Sicilia $(V, 17)$ mencione que Eivissa, a pesar de su moderada fertilidad, posee una pequeña región de viña, junto con olivos injertados en acebuches. En sentido contrario, Diodoro indica una ausencia total de producción de vino en las Islas Baleares, aunque sus habitantes estaban excesivamente inclinados a su consumo. Intervenciones recientes en la isla de Eivissa han documentado zanjas excavadas en el subsuelo rocoso para la plantación de vides, reivindicando de paso este patrimonio arqueológico no bastante valorado (López Garí y Marlasca 2012).

La cerámica ática de barniz negro es prácticamente la única incluida en el estudio de la vajilla

(3) El trabajo del metal (en bronce) probablemente existió en este período, como en el anterior, a pequeña escala, dada la necesidad de importar el estaño.

Trab. Prehist., 70, N. ${ }^{\circ}$ 2, julio-diciembre 2013, pp. 315-331, ISSN: 0082-5638

doi: $10.3989 /$ tp.2013.12115 


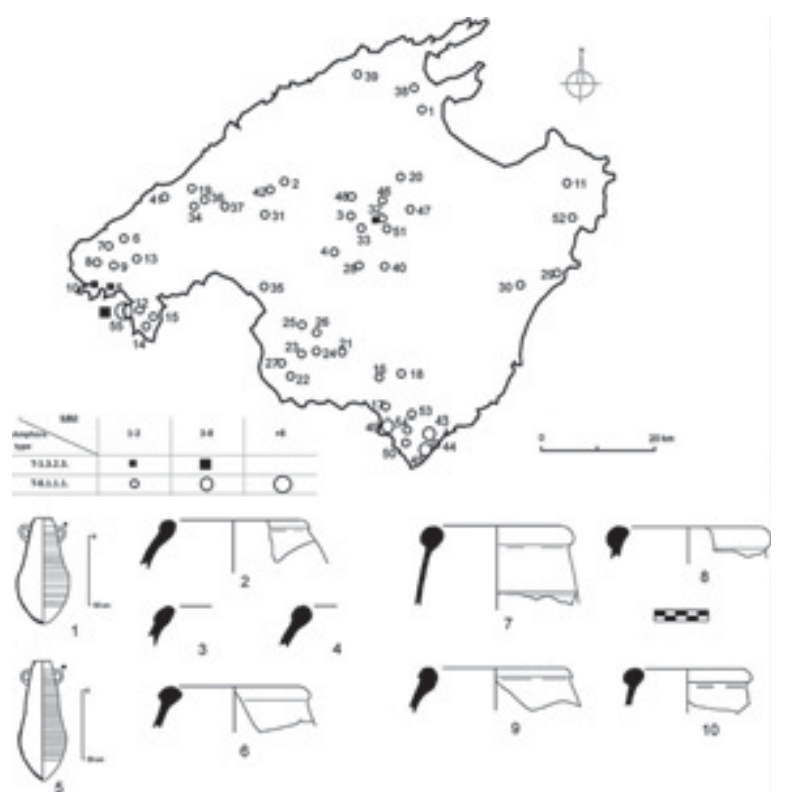

Fig. 2. Ánfora de comparación del tipo 1.3.2.3. (1) (Ramon 1991) e individuos recuperados en Puig de sa Morisca (2), Túmul de Son Ferrer (3) y Puig des Moros (4) (Aramburu 2004). Ánfora de comparación del tipo 8.1.1.1. (5) (Ramon 1991) y bordes hallados en Puig de sa Morisca (6-8), Túmul de Son Ferrer (9) y Ses Païsses (10) (Quintana 2006). Dispersión de los tipos 1.3.2.3. y 8.1.1.1., datados entre 450 y 400 a.C., y 400 y 300 a.C., respectivamente; tamaño del símbolo de acuerdo al recuento del Número Mínimo de Individuos (NMI); datos obtenidos mediante prospección arqueológica. 1. Ca na Bàssera, 2. Son Perot-Es Bosquets, 3. Can Verd, 4. Son Veny, 5. Son Fortuny, 6. S'Alqueria, 7. S'Olivar Vell, 8. Camí de Morella, 9. Pla de Son Forners, 10. Sa Vinya des Metge, 11. Son Catiu, 12. Es Fornets, 13. Sa Torrota, 14. Ses Penyes Rotges, 15. Sa Vinya-Son Sastre, 16. Son Perot, 17. Sa Barrala, 18. S'Alqueria Fosca, 19. Es Bosquet, 20. Son Gil de Dalt, 21. Sa Talaia, 22. Capocorb Vell, 23. Gomera, 24. Can Moger, 25. Cas Frares, 26. Es Pedregar, 27. S'Àguila d'en Quart, 28. Es Figueral, 29. Sa Gruta, 30. Taiet, 31. Es Puig Blanc, 32. Puig des Moros, 33. Galiana, 34. Sarrià, 35. Son Oms Vell, 36. Sa Sínia, 37. Cas Jai, 38. Bóquer, 39. Pedruixella, 40. Sa Figuerassa, 41. Son Balaguer, 42. Can Moragues, 43. Rafal des Porcs-Es Balç, 44. Rafal des Porcs-Es Favassos, 45. Sa Talaia Grossa, 46, Es Meià, 47. Son Baró, 48. Binifat, 49. Campaments d'explotació de la sal, 50. Sa Vinya, 51. Putxet d'en Font, 52. Es Picó, 53. Rafal Llinàs-Na Mera Petita, 54. Antigors, 55. Puig de sa Morisca.

fina (Fig. 3). Además consideramos dos fragmentos de cerámica de figuras rojas, recuperados en excavaciones en el santuario de Son Mas. Pertenecen a sendas cráteras de campana procedentes

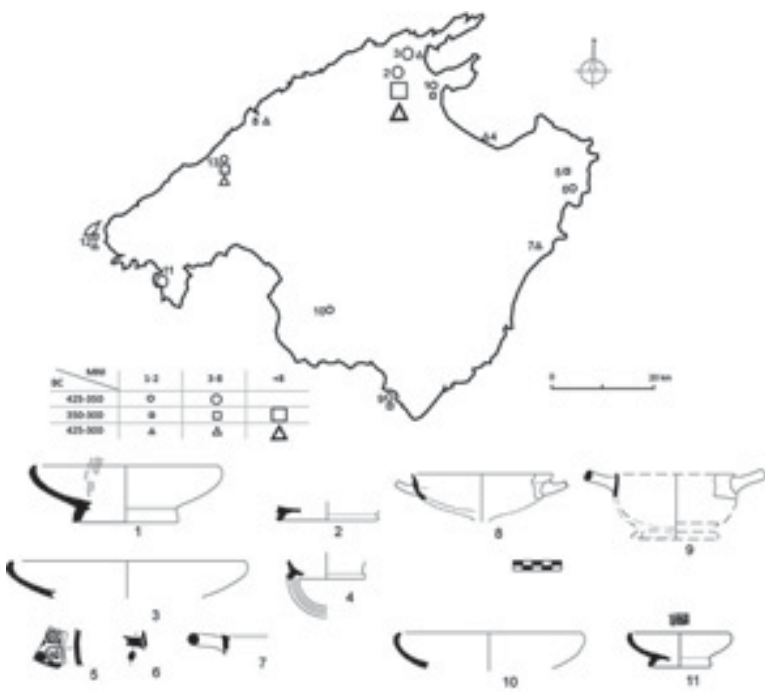

Fig. 3. Cerámica ática de barniz negro de Son Mas, formas Lamboglia 21 (Lamboglia 1952) (1 y 3), Bolsal -Lamboglia $42 \mathrm{Ba}-$ (2), Skyphos -Lamboglia 43- (4), fragmento decorado de figuras rojas (5) y fragmento de asa de cerámica ática de barniz negro (6). Skyphos tipo 744-763 procedente de Puig de sa Morisca (7) y Kylix (8), Bolsal -Lamboglia 42- (9) y Lamboglia 21/forma 2770 de tamaño grande (10) y pequeño (11) del yacimiento de La Punta (Cerdà 2002). Dispersión de la vajilla fina entre el 425-350 y 350-300 a.C. o, indistintamente, entre $c a$. 400-300 a.C.; tamaño del símbolo de acuerdo al Número Mínimo de Individuos (NMI). Datos obtenidos mediante prospección arqueológica y prospección. 1. Pollentia, 2. Sa Punta, 3. Gotmar, 4. Illa des Porros, 5. Sa Cova, 6. Ses Païsses, 7. Son Carrió, 8. Puig d'en Canals, 9. Na Guardis, 10. Son Taixaquet, 11. Puig de sa Morisca, 12. Cova des Moro o de sa Font (Dragonera), 13. Son Mas.

de Apulia, datada en la segunda mitad del siglo IV a.C., y del Ática.

En resumen, el concepto de fósil director orienta esta investigación que excluye, en buena medida, una aproximación a las facies cerámicas, por ser muy escasos los contextos homogéneos que pueden ser datados en el período estudiado.

Los materiales proceden de la isla de Mallorca o de los islotes cercanos a ella. Se omiten los objetos del cargamento del pecio de El Sec, a pesar de ser el único datado en el siglo IV a.C. y haberse hallado en aguas de Mallorca, porque algunos nunca han sido recuperados en tierra firme, lo que plantea dudas razonables sobre su destino. $\mathrm{Al}$ analizar las posibles rutas comerciales seguidas por el barco, Arribas et al. (1987: 655) apuntaron 
destinos desde la costa del Languedoc al sudeste peninsular, excluyendo implícitamente Mallorca.

Los materiales arqueológicos tienen orígenes diversos por lo que se les han aplicado diferentes niveles de análisis. Los datos sobre las ánforas proceden de tres fuentes principales: prospecciones arqueológicas no intensivas e intensivas y excavaciones arqueológicas. La cerámica fina ha sido obtenida sobre todo de la última fuente $\mathrm{y}$ algunos individuos de la primera.

La información sobre las prospecciones no intensivas procede del Inventario de Yacimientos Arqueológicos de Mallorca (Aramburu-Zabala 2004), deudor de los trabajos enciclopédicos de Mascaró Pasarius (1961-67, 1967, 1968) y la Carta Arqueológica de Mallorca, básicamente un recurso de gestión de la administración local. Otros datos se han recuperado en la bibliografía especializada, sobre todo en Joan Ramon (1991, 1995). Unas pocas muestras han sido localizadas durante esta investigación. Las prospecciones arqueológicas intensivas se han concentrado en el yacimiento del Puig de sa Morisca (Quintana 2000).

Los datos proporcionados por las excavaciones arqueológicas proceden de cuatro grandes asentamientos autóctonos: Puig de sa Morisca, Son Fornés, S'Hospitalet Vell y Ses Païsses. Otros yacimientos indígenas excavados aportan un caudal menor de información, aunque no por ello cualitativamente menos importante: los santuarios de Son Mas y Sa Punta des Patró, la cueva junto a la necrópolis de La Punta, la necrópolis de S'Illa des Porros, el túmulo escalonado y necrópolis de Son Ferrer, los talayots de Son Fred y Cascanar, el pequeño asentamiento del Turó de ses Beies o el yacimiento indígena existente bajo la ciudad romana de Pollentia. Los yacimientos ebusitanos de Es Trenc y Na Guardis también se consideran en este apartado.

Estos datos han sido analizados según criterios cualitativos (presencia/ausencia) y cuantitativos (número mínimo de individuos -NMI), utilizando, en su caso, mapas de dispersión (mapping). La cronología de las ánforas ebusitanas (tipos 1.3.2.3. y 8.1.1.1.) oscila entre la segunda mitad del siglo V y el siglo IV a.C. (Figs. 2 y 4) y la de las cerámicas de barniz negro, entre la primera y la segunda mitad del siglo IV a.C. (Fig. 3). Los resultados se han contrastado con la dispersión del ánfora ebusitana del siglo III a.C. (tipos 8.1.2.1. y 8.1.3.1.) (Fig. 5).

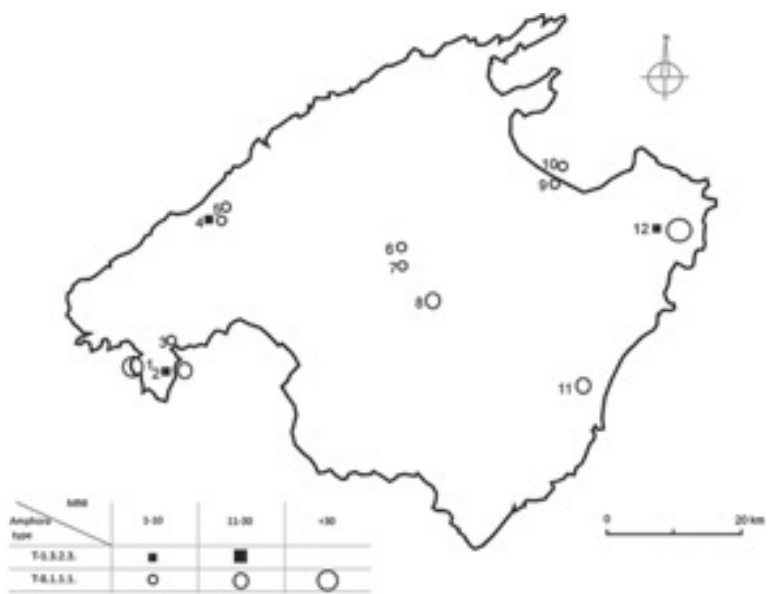

Fig. 5. Dispersión de los tipos anfóricos 1.3.2.3 (450-400 a.C.) y T.8.1.1.1. (400-300 a.C.); tamaño del símbolo de acuerdo al Número Mínimo de Individuos (NMI); datos obtenidos mediante excavación; 1. Puig de Sa Morisca, 2. Son Ferrer, 3. Turó de Ses Beies, 4. Son Ferrandell, 5. Son Mas, 6. Son Fred, 7. Cascanar, 8. Son Fornés, 9. Punta des Patró, 10. Illa des Porros, 11. S'Hospitalet Vell, 12. Ses Païsses.

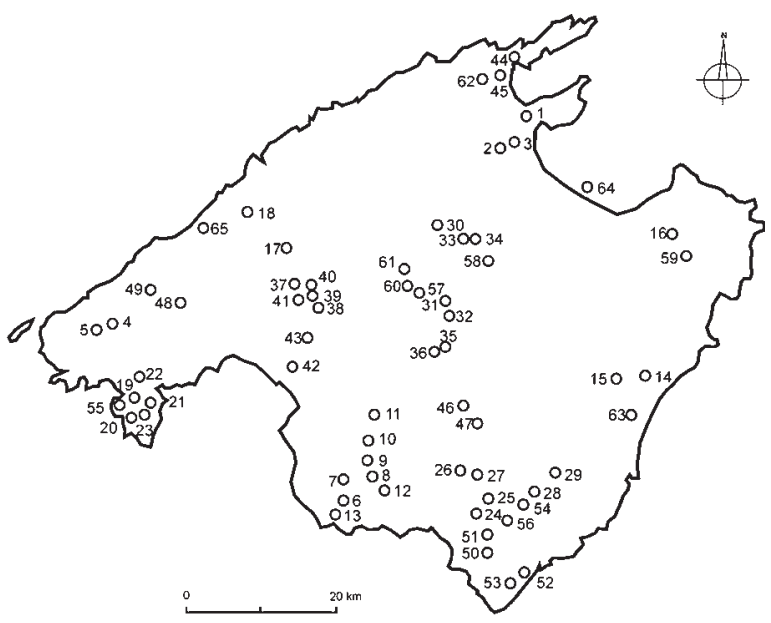

Fig. 5. Dispersión de los tipos anfóricos T.8.1.2.1 y T.8.1.3.1, indistintamente. Dichos tipos se datan entre 300-250 a.C. y 250-200 a.C., respectivamente; datos obtenidos mediante prospección arqueológica.

Aunque no se pretende estudiar la dinámica histórica, la comparación nos permite reconocer de manera más clara tendencias definidas en el siglo IV a.C. al existir más ejemplares y yacimientos del siglo III a.C. Como la cerámica fina

Trab. Prehist., 70, N. ${ }^{\circ}$ 2, julio-diciembre 2013, pp. 315-331, ISSN: 0082-5638

doi: $10.3989 /$ tp.2013.12115 
es muy escasa en el siglo III a.C., no se presenta ningún mapa comparativo.

Para el análisis cualitativo de los datos obtenidos en excavaciones el NMI se ha recalculado en base a la superficie excavada en cada yacimiento, puesto que la cifra absoluta de ejemplares depende de la extensión de las zonas excavadas, de su funcionalidad en el pasado o de los fenómenos postdeposicionales que las afectan. Lógicamente la cantidad de ánforas diferirá entre los lugares de almacén o basureros y los espacios rituales donde suele aparecer vajilla para el consumo de líquidos (presumiblemente vino), al menos en los contextos baleares. El volumen de sedimento extraído sería un factor de corrección más adecuado que el área, pero los datos disponibles impiden calcularlo. Un segundo factor corrector es la cronología de producción estimada para cada tipo anfórico: 50 años para las T-1.3.2.3. y 100 para las T-8.1.1.1.

Los datos provenientes de los escasos pero fiables contextos arqueológicos del siglo IV a.C. han sido analizados cualitativa y cuantitativamente, cuando ha sido posible. Este análisis puede usarse como factor de control y señala tendencias respecto a la llegada de otros materiales cerámicos coetáneos. Este hecho deberá ser confirmado en el futuro ampliando el registro.

\section{PRESENTACIÓN DE LOS DATOS Y RESULTADOS}

Los hallazgos en prospección arqueológica de ánforas ebusitanas del siglo IV a.C. (T-8.1.1.1) están muy concentrados en el sur y oeste de la isla. En el sur, el primer loci son los yacimientos del islote de Na Guardis y de la playa de Es Trenc (probablemente solo un muelle con unas pocas estructuras permanentes), cercanos a los supuestos campamentos de explotación de la sal en la Colònia de Sant Jordi y considerados lugares usados por los comerciantes ebusitanos (Guerrero 1987, 1997). Sin embargo, la explotación de la sal a una escala notable no ocurre hasta el Alto Imperio Romano, como prueban los más de 190 bordes de ánfora de este período, frente a los 5 adscribibles al siglo IV a.C. (Guerrero 1987: 102). Los asentamientos indígenas de Sa Talaia Grossa y Rafal des Porcs-Punta des Baus, al este del cabo de Ses Salines constituyen el segundo foco.
La zona oeste incluye el importante asentamiento autóctono del Puig de sa Morisca, además de hallazgos procedentes del Pla de Mallorca, que definimos como "grupo central", y de lugares muy específicos, principalmente de áreas costeras del este y norte de la isla. El aislamiento relativo del grupo central destaca excepto por el sur. En este sentido, cabe mencionar la mayor extensión en épocas antiguas de la albufera de Muro (Morey 2009), en la bahía de Alcúdia, los pequeños macizos de la Sierra de Llevant (Artà, alrededor de 500 m.s.n.m.) y las montañas de Calicant y de Felanitx. Estos accidentes geográficos parecen actuar como límite de concentraciones poco intensas de materiales en el litoral oriental. Sin embargo, la naturaleza de las prospecciones impide asegurar si esa imagen se corresponde con deficiencias en las mismas o realmente refleja una realidad histórica. La escasez de hallazgos en el territorio adyacente a la bahía de Palma se explica por la urbanización de un extenso territorio sin recuperación de materiales. A ello se suma las dunas fosilizadas (S'Arenal) y el cambio significativo de la línea de costa desde los tiempos prehistóricos hasta la actualidad (Rosselló i Verger 2000: 120). En cambio, en esa zona se han localizado hallazgos que aparentemente discurren desde la costa hacia el interior, hasta el pie de la Sierra de Tramuntana.

Las ánforas T-1.3.2.3. no son significativas ni cuantitativa, ni cualitativamente, salvo el ejemplar hallado en el núcleo del Puig des Moros de s'Almudaina (IJAM-30012). Si la identificación es correcta (4), permitiría rastrear los mecanismos de distribución del vino hacia el centro de la isla desde la segunda mitad del siglo V a.C., hecho que no ha podido detectarse a finales del siglo VI, ni en la primera mitad del V a.C. (HernándezGasch 2009: 275 y fig. 279).

La comparación con el mapa de ánforas ebusitanas del siglo III a.C., en base a prospecciones arqueológicas, ofrece un panorama similar, subrayando algunos de los aspectos ya descritos (Fig. 5). La densidad de hallazgos es mayor en el sur y el suroeste de la isla y la conexión entre

(4) No estamos de acuerdo con la clasificación de Aramburu-Zabala (2004) como un ánfora T-1.3.1.2., ya que la inclinación de la pared no responde, en absoluto, a un contenedor de este tipo. Dando por buena esa inclinación, estaríamos ante una T-1.3.2.3. y, aún así, aunque la pared externa del labio aparece poco exvasada, la curvatura interna es más parecida a la que suelen ofrecer las T-8.1.1.1. que al estándar de las T-1.3.2.3. 
estos grupos y el central del Pla de Mallorca resulta más evidente. Este muestra su aislamiento con respecto a otras zonas, a pesar de crecer algo hacia el Norte. El grupo meridional se amplía también hasta las últimas vertientes sudoccidentales de la Sierra de Llevant. A su vez, se observa de nuevo perfectamente el grupo occidental y se refuerza la vía de penetración al interior desde la bahía de Palma. El resto de hallazgos está asociado con asentamientos costeros.

La distribución de la vajilla fina, mayoritariamente compuesta por cerámica ática de barniz negro, refleja un fenómeno costero en Mallorca y en algunos islotes cercanos (Sa Dragonera y S'Illot des Porros). El NMI es reducido, excepto en el santuario de Son Mas y la cueva auxiliar o bothros de la cueva funeraria de La Punta, los dos yacimientos de carácter ritual. A diferencia de las ánforas contemporáneas, no se concentran en ninguna zona y su número es igualmente escaso en todas.

El número de ejemplares datados entre 450/425 y $375 / 350$ a.C. es similar al de los encuadrados entre el 350-300 a.C. Un tercer grupo, que cubre todo el siglo IV a.C., no permite distinguir si la distribución de la cerámica de lujo incide más en un momento temprano o más tardío. El santuario de Son Mas es uno de los yacimientos con más vasos recuperados. La ausencia del ánfora vinaria ebusitana T-1.3.2.3. podría indicar una cronología ya plenamente del siglo IV a.C. para los ejemplares de vajilla fina. De todas formas, entre los 2.262 fragmentos de cerámica de importación inventariados en la segunda mitad de los 1990 (5), solamente se detectaron 2 bordes de ánfora T-8.1.1.1. que De Mulder et al. (2007: 363) elevan a 10. Esta baja incidencia de T-8.1.1.1. y la ausencia de $\mathrm{T}-1.3 .2 .3$. pueden indicar una escasa penetración de los rituales del vino en Son Mas en este momento concreto. En las excavaciones en el cercano yacimiento de Son Ferrandell se han hallado 9 ánforas del tipo 8.1.1.1. (De Mulder, com. pers.), a las que se pueden añadir 2 bordes del tipo 1.3.2.3., prueba de que el comercio púnico ya estaba activo en este área en la segunda mitad del siglo V a.C. Así pues, los individuos más antiguos de cerámica fina de Son Mas bien pudieron haber llegado en dicho período y no solo como objetos ya antiguos en épocas más recientes.

(5) El inventario se debe a Conde, Hernández-Gasch y Principal.
Los datos procedentes de excavación constituyen otro elemento de contrastación de los fenómenos observados. Para el momento más antiguo, representado por las T-1.3.2.3., hay 4 individuos en el Puig de sa Morisca y 3 en Ses Païsses. La superficie excavada en estos asentamientos (unos $300 \mathrm{~m}^{2}$ hasta 2003 y $1450 \mathrm{~m}^{2}$ hasta 2008, según Aramburu y Hernández-Gasch 2005; Aramburu 2009, respectivamente) arroja índices muy bajos: 0,013 y 0,002 ánforas por $\mathrm{m}^{2}$. Aún así, la proporción es 6,5 veces mayor en el Puig de sa Morisca. La ausencia de datos obedece en las zonas sur y suroeste a la carencia de excavaciones, mientras que, en un poblado largamente excavado como Son Fornés $\left(2700 \mathrm{~m}^{2}\right.$ hasta 2011 -Gili, com. pers.), se señala la escasez de vino en el Pla de Mallorca hasta el siglo IV a.C. Ello concuerda con lo sugerido por los datos proporcionados por las prospecciones arqueológicas.

Los individuos de T-1.3.2.3. en yacimientos excavados en el norte y nordeste se reducen a los de Son Ferrandell ya mencionados. Ello sorprende en cierta medida, toda vez que, en la zona, Son Mas y La Punta han proporcionado vajilla fina que puede datarse en la segunda mitad del siglo V a.C. Incluso Punta des Patró tiene cerámicas más antiguas que pueden retrotraerse hasta finales del siglo VI a.C., en consonancia con las ánforas ebusitanas más antiguas, recuperadas en la zona, del tipo 1.3.1.2. ( $c a$. 525-450 a.C.) del Pedret de Bóquer (HernándezGasch 2009: 275 y fig. 279). No obstante, el total de individuos de los tipos más antiguos, tanto de vajilla fina como de ánforas, es siempre bajo. La ausencia de ánforas T-1.3.2.3. se debe probablemente a las limitadas excavaciones en algunos de los yacimientos citados y al carácter ritual de otros (Son Mas, La Punta y Punta des Patró).

El panorama cambia efectivamente en el siglo IV a.C. cuando la gradual penetración del ánfora $\mathrm{T}-8.1 .1 .1$. hacia el interior de la isla, mostrada en el mapa de prospecciones (Fig. 2), se combina con su aumento cuantitativo en toda Mallorca, indicado por las excavaciones arqueológicas. El factor de corrección que introduce considerar la duración de la fabricación de los distintos tipos de ánforas no afecta a este incremento neto. El ajuste de las cifras brutas de ejemplares recuperados con las superficies excavadas proporciona una estimación más precisa de esta dinámica.

En el asentamiento occidental del Puig de sa Morisca, interpretado hasta ahora como un cen-

Trab. Prehist., 70, N. ${ }^{\text {o }}$ 2, julio-diciembre 2013, pp. 315-331, ISSN: 0082-5638

doi: $10.3989 /$ tp. 2013.12115 
tro de comercio autóctono, el índice arroja unos resultados de 0,08 (NMI de 21), mientras que en el asentamiento subsidiario del Turó de ses Beies (unos $385 \mathrm{~m}^{2}$ publicados) el índice es de 0,005 ( 2 individuos), y en el asentamiento funerario del Túmul de Son Ferrer (unos $140 \mathrm{~m}^{2}$ excavados), cercano al Puig de sa Morisca, el índice es de 0,16 (NMI de 23). A su vez, en el asentamiento oriental de Ses Païsses, ubicado a una distancia relativamente alejada de la costa, el índice es de 0,04 (NMI de 63). En el cuarto poblado, S'Hospitalet Vell (unos $500 \mathrm{~m}^{2}$ excavados hasta 1983), el índice es de 0,02 (NMI de 12). En el centro de Mallorca, el asentamiento de Son Fornés (unos $760 \mathrm{~m}^{2}$ hasta 1988) tiene un índice similar de 0,03 (NMI de 26). Los talayots excavados en esta área son Cascanar (unos $153 \mathrm{~m}^{2}$ excavados) y Son Fred (unos $84 \mathrm{~m}^{2}$ excavados). Muestran índices de 0,01 ( 2 individuos) y 0,02 ( 2 individuos), respectivamente, aunque vale la pena señalar que estos lugares tuvieron un uso peculiar, probablemente no comparable al de los verdaderos asentamientos. De modo parecido, los santuarios de Son Mas (unos $400 \mathrm{~m}^{2}$ excavados), en el noroeste, y Punta des Patró, en el noreste, arrojan cifras muy distintas. El primero tiene un NMI bajo (2 o 10 individuos según los diferentes recuentos), con índices de 0,005 o 0,025, mientras que en el segundo (unos $185 \mathrm{~m}^{2}$ excavados) el índice es de 0,01 (NMI de 2). El cercano cementerio de Illa des Porros (unos $255 \mathrm{~m}^{2}$ excavados) muestra un índice de 0,004 (un individuo).

Estas cifras alteran el panorama indicado por las cifras brutas (NMI) que se reflejan en el mapa (Fig. 4). Puig de sa Morisca, sobre la costa oeste, duplica las ánforas por $\mathrm{m}^{2}$ de Ses Païsses, en el área noreste $(0,08$ y 0,04 , respectivamente). El segundo coeficiente es similar al apreciado en Son Fornés, en el centro de la isla $(0,03)$. El último yacimiento investigado, S'Hospitalet Vell, un asentamiento relativamente interior ubicado en el este de Mallorca, tiene también un índice bajo $(0,02)$, probablemente por las limitaciones en los datos publicados, aunque las excavaciones actuales han sacado a la luz nuevos individuos (Salas, com. per.). A su vez, el Túmul de Son Ferrer destaca por su índice alto $(0,15)$, dado que los coeficientes de los lugares rituales suelen presentar índices bajos, entre 0,02 y 0,01 o incluso inferiores.

Finalmente, mencionamos que los contextos que pueden ser datados en el período analizado son extremadamente escasos. El nivel II2 de la casa denominada HPT1 de Son Fornés es el único contexto publicado hasta ahora fechable de manera inequívoca en el siglo IV a.C. Este nivel representa el último uso previo al primer abandono y contiene algunos fragmentos de ánfora ebusitana y una pátera con el mismo origen, del tipo 2.6.e (Palomar 2005: 121). Esta forma probablemente está inspirada en un prototipo de cerámica ática de barniz negro (Sparkes y Talcott 1970: 137-138 y 303 , pl. 9, n. 949), datado hacia el 500-325 a.C. (Fernández y Granados 1980: 39-40). En el edificio HPT4 se identificaron algunos individuos contextualizados de T-8.1.1.1. Sin embargo, en este caso fueron las únicas importaciones recuperadas (Palomar 2005:128-129).

En la parte alta del Puig de sa Morisca se excavó una torre entre los años 1997 y 2000 . De la preparación de su pavimento se recuperaron el borde de una kylix, aparentemente de mediados del siglo $\mathrm{V}$ a.C., y el labio y asa de un cuenco con un asa, ambos de cerámica ática de barniz negro (Quintana y Guerrero 2004: 254-255). Este último fragmento, tras su examen para el presente estudio, se ha incluido en el tipo 744-763 (Sparkes y Talcott 1970), fechable entre 500 y 300 a.C. Los niveles de ocupación interiores de la torre, datados en el siglo IV a.C., contienen diversos objetos que requieren un examen minucioso. Los tipos representativos incluyen 13 ánforas púnicoebusitanas T-8.1.1.1., así como 2 ánforas de la costa ibérica y 1 de Masalia (Quintana y Guerrero 2004: 255-256). Otros tipos cerámicos son 2 boles de labio entrante ebusitanos, similares a algunos encontrados en Eivissa. Se fechan entre finales del siglo V y la primera mitad del IV a.C. y en la segunda mitad del siglo IV a.C., respectivamente. Además hay un plato y un mortero ebusitanos, más una parte del labio y asa de una cerámica de cocina, probablemente de origen cartaginés.

En el poblado de Ses Païsses, una de las habitaciones se abandonó a finales del siglo $\mathrm{V}$ a.C., a tenor de la aparición de una copa Cástulo completa y fragmentos de dos ánforas ebusitanas del tipo 1.3.2.3. (Sanmartí et al. 2002: 115). Entre los contextos cuantificados del siglo IV a.C. hallados en un área al aire libre, la cerámica de importación solo supone el 3\% del NMI y el 6\% del total de fragmentos, siendo el resto cerámica a mano de factura local. Las ánforas constituyen el $67 \%$ y el $83 \%$, respectivamente. El tipo 8.1.1.1. 
alcanza el 94\% de todos los fragmentos. También se recuperaron un fragmento de ánfora ibérica y otro de greco-itálica. Un 33\% del NMI y un 17\% de los fragmentos pertenecen a cerámicas finas o comunes. De hecho, existen dos ejemplares producidos en 'YBŜM/Ebusus y otro, en la costa ibérica (Sanmartí et al. 2002: 116).

Las cifras calculadas para los bienes de importación en los contextos del siglo IV a.C. del santuario de Punta des Patró (Sanmartí et al. 2002: 116) oscilan entre $10,4 \%$ (NMI) y $21,6 \%$ (número de fragmentos). Según el NMI la producción principal es el ánfora ebusitana (36,4\%), seguida por la ibérica $(18,2 \%)$. También se recuperaron fragmentos de producciones anfóricas púnicas del Mediterráneo Central, masaliotas, greco-itálicas y corintias (tipo B). Entre las cerámicas finas y comunes, se halló un fragmento de lucerna ática, otro fragmento de barniz negro de origen indeterminado y algunos de cerámica ebusitana (Sanmartí et al. 2002: 109).

En el islote de $\mathrm{Na}$ Guardis, en el nivel anterior a la construcción de las instalaciones de la base ebusitana, se hallaron ánforas T-8.1.1.1. asociadas a dos platos ebusitanos (Lamboglia 21/25) (Guerrero 1984: 209), un ánfora PE 22 (375/350225/200 a.C.) y una jarra ebusitana del tipo Eb-69 (Guerrero 1997: 44).

El panorama resultante de los contextos excavados claramente muestra dos aspectos diferentes no detectados en la distribución de hallazgos en los mapas ya analizada. Primero se distingue una mayor variabilidad de productos en los asentamientos costeros. Entre las ánforas, aparte de las ebusitanas, encontramos algunas ibéricas, masaliotas, centro-mediterráneas, greco-itálicas e incluso corintias. Entre las producciones cerámicas importadas, además del barniz negro ático y sus imitaciones ebusitanas, puede hallarse cerámica común ebusitana, cartaginesa e ibérica. Por otro lado, en el centro de Mallorca se detecta una significativa restricción de productos con un claro predominio del material ebusitano y ausencia de bienes importados de Masalia o Corinto o de productos de lujo, como la vajilla ática de barniz negro.

\section{DISCUSIÓN Y CONCLUSIONES}

Durante los siglos IX al VI a.C., los fenicios crearon una red de asentamientos en el Extremo
Occidente (6). Al menos en principio su presencia parecía obedecer al establecimiento de una red comercial a escala mediterránea (Delgado 2008). En el Extremo Occidente esta red permitía el acceso de los fenicios a productos minerales, en especial cobre y plata, y también a productos agropecuarios, probablemente en un momento posterior (Alvar 1999; López Castro 2008). Parece que los fenicios actuaron de manera diferente según el tipo de territorio. Según Delgado (2008), en Andalucía occidental, los fenicios implantaron sus propias estructuras en los mismos núcleos indígenas tartésicos, estableciendo un comercio directo con ellos. En cambio en Andalucía oriental, las primeras fundaciones escogen lugares deshabitados y parecen ser más puntos de escala que de comercio con la población autóctona.

Los tipos y las etapas de los contactos entre fenicios e indígenas se explicaron mediante modelos que definían las formas del comercio fenicio. En el Extremo Occidente, y más específicamente en la Península Ibérica, los sistemas de comercio entre los fenicios, y por extensión púnicos, y las comunidades locales han sido estudiados desde los años 1990 según dos orientaciones historiográficas. Una línea de investigación temprana puso el acento en el elemento fenicio, relegando al indígena. Alvar (1999) y López Castro (2000) articularon estos modelos de comercio que, con el paso del tiempo, evolucionan hacia otros nuevos. Alvar (1999) los denomina "Modo de contacto no hegemónico" y "Modo de contacto sistemático", mientras que López Castro (2000) los define como "Comercio aristocrático" y "Comercio maqom" o "empórico".

La segunda línea de investigación da mayor papel al elemento indígena en el marco de los intercambios (Aubet 1994; Ruiz-Gálvez 1998; Arruda 2002; Vives-Ferrándiz 2005). Sus proponentes están de acuerdo con los postulados postcoloniales que se han aplicado a la arqueología en otros escenarios geográficos (Van Dommelen 1998; Gosden 2004). Sus modelos refuerzan la idea de que, en el intercambio entre fenicios y

(6) Se ha argumentado una presencia oriental en Huelva en un momento tan antiguo como el siglo X a.C. (Mederos 2006), a partir de algunos hallazgos controvertidos (Moreno Arrastio 2008: n. 47), por lo que la mayoría de los autores mantiene una actitud prudente al respecto (Blázquez 2007: 65; Delgado 2008: 22; González et al. 2008: 63; Wagner 2008: 11).

Trab. Prehist., 70, N. ${ }^{\circ}$ 2, julio-diciembre 2013, pp. 315-331, ISSN: 0082-5638

doi: $10.3989 /$ tp. 2013.12115 
élites autóctonas, opera un factor de igualdad. Los primeros buscarían establecer relaciones con sociedades cuya organización y capacidad tecnológica fueran suficientes para permitirles acceder al flujo comercial (Vives-Ferrándiz 2005). En este caso los autores que tratan el fenómeno colonial suelen usar términos como "colonialismo" o "colonización" para referirse a los mismos hechos históricos. Según Vives-Ferrándiz (2005), el primer término aparece especialmente en la bibliografía anglosajona y el segundo en la de los países del sur de Europa. Los autores franceses, españoles e italianos tienden a evitar el término "colonialismo", al considerarlo una reminiscencia de las situaciones coloniales recientes. Dietler (2010: 12) reconoce la omnipresencia del concepto en las ciencias sociales y un amplio consenso respecto a su importancia que, sin embargo, no alcanza a su precisa definición. Se hace necesario, en este punto, aclarar la nomenclatura usada en este trabajo. Siguiendo a Dietler (2009), cuando usamos "colonización", nos referiremos a una situación de dominación política impuesta por agentes externos sobre un territorio y una población específica. Al usar "colonialismo" aludimos a un conjunto de proyectos y prácticas de control llevadas a cabo en las relaciones asimétricas de poder entre distintas sociedades, junto a los probables procesos culturales y sociales derivados de ellas.

En Mallorca, Guerrero (1981, 1984a, 1984b, 2004) fue el único investigador que se centró específicamente en las cuestiones coloniales, describiendo una sociedad autóctona de carácter tribal estructurada en torno a jefaturas o cacicazgos, chiefdoms (Guerrero 1997: 275-277). No consideró dicha estructura social como una consecuencia directa del contacto con los comerciantes ebusitanos, pero sí que la relación intensificó rasgos ya existentes. A la vez que las jefaturas habrían incrementado su poder coercitivo, habrían surgido o se habrían profundizado las diferencias sociales y las formas de jerarquización social y de dependencia (Guerrero 1997: 303). Dicho planteamiento fue criticado desde una perspectiva teórica y en base a los datos disponibles en Mallorca (Lull et al. 1999: 68). Guerrero (1997: 304) considera explícitamente la dialéctica centro-periferia como una herramienta básica para el análisis de los procesos coloniales. Entiende, como antes algunos economistas (Amin 1975, 1976 apud Guerrero 1997), que la colonización implica inevitablemente relaciones asimétri- cas entre dos culturas, lo que provoca un comercio desigual. Guerrero también afirma, siguiendo a Wagner (1993), que las diferentes escalas de valor otorgadas a los bienes intercambiados provocan profundas relaciones de desigualdad.

Más recientemente, la arqueología postcolonial ha criticado los esquemas unilaterales procesualistas que asignan a los indígenas un papel pasivo en el proceso colonial. También ha señalado las diferentes escalas de valor existentes entre los elementos colonizadores y las comunidades autóctonas (Krueger 2008). La recepción de productos inaccesibles en el propio entorno social refuerza el poder de quien los posee. Desde este punto de vista, el intercambio se vuelve totalmente justo y equilibrado.

En la última década, Guerrero (Guerrero et al. 2002; Guerrero 2004) aplicó a Mallorca los modelos de intercambio desarrollados por Alvar (1999) y López Castro (2000) para las dinámicas previamente vistas de la Península Ibérica. Sobre esa base, la cronología y naturaleza de los contactos entre los fenicios y púnicos, asentados en la vecina isla de Eivissa, y las comunidades autóctonas de Mallorca habría presentado dos momentos diferenciados. El primero habría tenido lugar entre el 850 y el 400 a.C. Está caracterizado por los denominados intercambios aristocráticos donde los regalos se presumen restringidos a las clases sociales superiores. La fecha inicial es bastante problemática. No casa con la cronología del asentamiento fenicio más antiguo en la isla de Eivissa, Sa Caleta, construido en torno al 700 a.C. y con un escaso recorrido cronológico. Con todo no se descartan algunos posibles intercambios entre comerciantes y comunidades autóctonas en el siglo VIII a.C. (Ramon 2005, 2007). La necrópolis más antigua de la ciudad de 'YBŜM'/Ebusus está datada en el siglo VI a.C. a partir de cuatro dataciones radiocarbónicas, si bien la UtC-11186, $2771 \pm 38$, calibrada a $1 \sigma$, arrojó una fecha de calendario de 895-820 cal a.C. (Fernández y Costa 2004: 328). Esta fecha tan elevada permanece sin explicar, ya que es totalmente discordante con la cronología arqueológica de la propia necrópolis. Además precede en tres siglos las primeras importaciones halladas en Mallorca (Hernández-Gasch 2009).

La segunda fase se desarrollaría entre el siglo IV a.C. y la conquista romana de Mallorca en el 123 a.C. Ha sido denominada como "coloniza- 
ción plena" y se basa en el comercio empórico y en ciertas relaciones de poder (Guerrero 2004: 171). En este momento, tres aspectos diferentes completan el marco colonial: el reclutamiento de mercenarios para el ejército cartaginés, la fundación de bases ebusitanas en la costa y, por último, el control y explotación de recursos estratégicos como las salinas del sur de Mallorca.

Esta visión fue compartida por investigadores que trataban el tema colonial en las Baleares (Quintana 2000; Quintana y Guerrero 2004; Calvo et al. 2009). Cabe destacar el trabajo de Calvo et al. (2009) donde se aceptan las fases de comercio aristocrático y comercio empórico/ maqom, pero se subraya la posibilidad de un mayor protagonismo del elemento autóctono en el intercambio exterior, especialmente con 'YBŜM'/ Ebusus. En concreto el yacimiento autóctono, Turó de ses Beies, se interpreta como un centro receptor de bienes localizado en el oeste de la isla que ejercería una misión similar a la base ebusitana de $\mathrm{Na}$ Guardis, en el sur. Otros autores discrepan de esta interpretación y consideran al yacimiento como una granja indígena (Salvà y Hernández-Gasch 2009).

Los modelos aristocrático y empórico/maqom para el caso de Mallorca han sido puestos en tela de juicio recientemente por algunos miembros de la Universidad de les Illes Balears (7).

Mayoral (1984) (8) trató el fenómeno colonial por los mismos años que Guerrero. En sus trabajos, manifestó que los bienes importados (cerámicas, collares de pasta vítrea y figuras de bronce) estaban relacionados con un proceso de adaptación cultural establecido entre los púnicos y las poblaciones autóctonas. Estas últimas estarían en una posición de desigualdad y su adaptación se llevaría a cabo mediante las relaciones de poder, encarnadas en las nuevas necesidades (Mayoral 1984: 1306). Tales relaciones, crecientemente desiguales, habrían constituido una manera de control de los colonizadores sobre los colonizados.

Hernández-Gasch (2009) ha expuesto un punto de vista distinto al analizar los contextos indígenas en relación con el cargamento del pecio de Cala Sant Vicenç en Mallorca. Tras considerar

(7) Véase n. 2.

(8) Mayoral, F. 1983: Aproximación al estudio de la fase postalayótica mallorquina: la cerámica. Tesis de licenciatura inédita. Universidad Autónoma de Barcelona. Barcelona. los materiales que pueden datarse entre $c .525 \mathrm{y}$ 450 a.C. en las Baleares, argumenta que existió un comercio griego en el norte de Mallorca, junto con un igualmente incipiente intercambio fenicio en el sur de la isla. Un elevado número de cambios en el plano social, ideológico y económico del mundo autóctono aparentemente se dieron en el mismo período (Hernández-Gasch 2009: 284). El autor asume explícitamente un rol activo de las sociedades autóctonas para crear las condiciones adecuadas para la atracción de elementos exógenos. Al mismo tiempo, interpreta que las citadas comunidades indígenas usaron los bienes de lujo foráneos para reforzar los cambios sociales, económicos y políticos. No obstante, este análisis se centra en un período breve y no trata las relaciones entre las comunidades autóctonas y los foráneos en períodos posteriores.

Recientemente se ha sugerido que el comercio exterior en las Islas Baleares durante el período arcaico no fue exclusivamente fenicio y ebusitano (c. 625-450 a.C.) (Hernández-Gasch 2009). Sin embargo, los investigadores coinciden en la relativa "inundación" de los mercados insulares con productos importados por los mercaderes de 'YBŜM'/Ebusus (Ramon 1991, 1995; Guerrero 1998) desde el siglo IV a.C. en adelante. Hasta la fecha, solamente las cerámicas provenientes de un pequeño número de yacimientos mallorquines han sido cuantificadas (Sanmartí et al. 2002; Quintana y Guerrero 2004; Quintana 2005) (9), habiéndose dado a conocer cómputos globales para el conjunto de la isla (Guerrero 1999). A día de hoy es posible actualizar estos datos agregando nuevos individuos cerámicos tanto publicados como inéditos. Sin embargo, el enfoque es completamente nuevo, ya que se intenta comparar las cifras en una dimensión territorial y también cronológica con respecto a períodos previos y posteriores. Ello es un medio para la interpretación de la dinámica de adquisición y transmisión de los diferentes bienes entre extranjeros y comunidades autóctonas y entre estas últimas.

La ausencia de una ocupación territorial de las Baleares por elementos púnicos es un hecho arqueológico e histórico. Lo refuerza el que la base ebusitana de $\mathrm{Na}$ Guardis pueda ser considerada un asentamiento estacional (Guerrero 1997: 126),

(9) Fayas, B. 2010: Las ánforas de Son Fornés. Su estudio tipológico y contextualización histórica. Tesis de licenciatura inédita, Universitat de les Illes Balears.

Trab. Prehist., 70, N. ${ }^{\circ}$ 2, julio-diciembre 2013, pp. 315-331, ISSN: 0082-5638

doi: $10.3989 /$ tp. 2013.12115 
ocupado durante los períodos del año en que el mar estaba abierto a la navegación. Entre las instalaciones del islote figuran almacenes y una forja (Guerrero 1997: 76), de manera que Na Guardis se interpreta como punto de recepción/redistribución y reparación de embarcaciones, además de como lugar de control de las cercanas salinas (Guerrero 1997: 249).

En ausencia de ocupación territorial, las comunidades autóctonas debieron de tomar un rol activo en la redistribución de bienes importados si, según parece, el contacto directo entre ebusitanos y las poblaciones baleáricas se limitó a lugares relativamente cercanos a la costa. Apoyan esta idea las grandes cantidades de ánforas halladas en los yacimientos más costeros y su decrecimiento hacia el interior, tendencia constatada en el curso de las excavaciones y prospecciones arqueológicas mencionadas. La exclusiva presencia de vajilla fina en los yacimientos más cercanos a la costa también apunta en esa dirección. No hay evidencias claras de si los comerciantes se desplazaban hasta los poblados situados en la franja costera, o si el presumible intercambio se llevaba a cabo en la propia línea de costa. La alta concentración de ánforas en la playa d'Es Trenc apunta a un consumo de vino, del que quizá no solo fueran responsables los ebusitanos que mantenían las instalaciones allí localizadas. En el Puig de sa Morisca, los intercambios debieron ocurrir en el poblado, que se sitúa en un promontorio a unos $800 \mathrm{~m}$ del mar. Le distinguen de otros poblados indígenas características morfológicas tales como una acrópolis con elementos monumentales (murallas y torres) que le prestigiaban.

Por último, cabe mencionar el reclutamiento de mercenarios. Como testifican las fuentes clásicas griegas y romanas, no se ajusta a un sistema de comercio basado solo en la línea de costa. Por el contrario, apunta a unas estrechas relaciones entre los autóctonos y las poblaciones foráneas, que habrían requerido un profundo conocimiento y cierta confianza entre ambas partes. En los últimos decenios algunos autores argumentaron que la mayoría de los productos importados por las comunidades baleáricas respondía a los salarios de los mercenarios enviados al extranjero (Guerrero 1989: 107; Gornés et al. 1992: 19; Lull et al. 2001: 74). La primera intervención de los honderos baleares de la que hay constancia sucede durante las guerras entre púnicos y griegos en Sicilia, en las batallas de Selinus e Himera en el año 409 a.C. y en Akragas en el 406 a.C. (Diodoro Sículo, XIII, 80, 2). A este respecto, recordamos que las ánforas T-1.3.2.3. y algunos barnices negros áticos (kylikes, copas Cástulo y bolsales) pudieron haber llegado durante este período, formando parte de las soldadas de estos primeros mercenarios. Algunas piezas cerámicas pudieron hacerlo antes en calidad de regalos para establecer acuerdos y dejar el camino expedito a las levas de tropas. Las siguientes batallas donde se menciona a los honderos son Eknomon, en el 311 a.C. y Gela, en el 311/310 a.C. Quizás las fuentes sean incompletas pero, en todo caso, lo más inverosímil sería poner en duda la llegada a Mallorca de las ánforas vinarias en el curso de la centuria. La T-8.1.1.1. se data entre el 400 y el 300 a.C. y es poco probable que la mayoría hubiese llegado al final de la centuria, especialmente cuando disponemos de algunos barnices negros datados en su primera mitad. Así pues, o bien los mercenarios intervinieron en otras batallas no registradas en las fuentes antiguas, llevándose a cabo levas durante todo el siglo, o bien existieron otros productos involucrados en las operaciones comerciales entre los distintos actores.

El transporte por tierra de dichos productos no es cuestión menor. Fenicios y púnicos usaban el carro de caballos para la guerra (Blázquez 1999: 122) y el carro tirado por bueyes para el transporte de mercancías aparece en relieves asirios del siglo VIII a.C. (Gómez de Caso 2005: fig. 3). Sin embargo faltan datos relativos a las poblaciones autóctonas de las Baleares. La presencia de caballo en los contextos locales es siempre baja y los valores de los bóvidos oscilan entre el $11 \%$ y el $18 \%$ en la Segunda Edad del Hierro en Mallorca, lo que significa un ligero retroceso respecto al período talayótico (Hernández et al. 2011: 129). El transporte en carro podía ser factible por pistas de tierra en llano como el existente entre la Marina de Llucmajor (tierras costeras del suroeste) y el Pla de Mallorca (tierras agrícolas del centro de la isla). No obstante, el diseño de las asas de las ánforas ebusitanas, muy pequeñas y redondas, parece adaptado para enhebrar una cuerda y ser llevadas a lomos de algún animal o bien, usando una verga, ser transportadas a hombros de porteadores, tal y como se muestra en la iconografía romana para tipos anfóricos más tardíos (Thomas-Vallon y Vallon de Montgrand 2006). En 
todo caso, está claro que las comunidades costeras recibieron antes los productos importados. Vale la pena recordar que la cerámica fina de lujo solo se ha recuperado en yacimientos ubicados en lugares relativamente cercanos al mar. Así pues, las comunidades más expuestas al contacto ebusitano retendrían ciertos elementos diacríticos frente a las clases inferiores y/o a los poblados sin contacto directo con la población semita.

Los mapas de distribución y cuantificación de los tipos cerámicos no ofrecen suficiente información respecto a qué asentamientos podrían actuar como distribuidores de los bienes. Para ensayar esta aproximación, hemos categorizados los yacimientos que ofrecen materiales del período analizado, considerando además otros importantes sin estos productos, pero que muy probablemente estaban operativos entonces. La ausencia de hallazgos responde a lagunas en las prospecciones y excavaciones, puesto que en visitas a estos núcleos hemos reconocido en superficie fragmentos de bordes de ánforas del tipo 8.1.1.1. Las categorías se han establecido en función del carácter habitacional o ritual (o específicamente funerario) de los yacimientos y a su entidad monumental:

1) Asentamientos rodeados de murallas: como estas se datan en el tránsito entre la Primera y Segunda Edad del Hierro indican un núcleo importante de población en este momento.

2) Asentamientos sin muros: algunos denominados centros ceremoniales tienen talayots y túmulos datados en la Primera Edad del Hierro, que demuestran la continuidad en el uso de los yacimientos. Sin embargo la población que hace uso de dichos lugares es probablemente reducida, como las actividades allí realizadas ya que no presentan murallas.

3) Talayots aislados: en algunos de los excavados hay estructuras adosadas, lo que señala cierta función habitacional, además de las de control del territorio y demarcación territorial de los poblados que ejercieron en época talayótica.

4) Estructuras aisladas con función indeterminada y yacimientos sin estructuras detectados por la presencia de cerámica. La naturaleza de unas y otros es incierta, pero está claro su uso por pequeños grupos y/o en tiempos cortos. Excluimos que sean verdaderos poblados.

5) Cuevas/ santuarios/ túmulos aislados: lugares comunales donde presuntamente se llevaban a cabo ciertos rituales. Algunos tienen un uso específicamente funerario.
Se han utilizado los datos disponibles para cada yacimiento, aunque como la mayoría están poco o nada excavados, la información es insuficiente. Además, esos yacimientos sufrieron diferentes formas de destrucción durante centurias, que podrían ocultar su clasificación. Las prospecciones arqueológicas también presentan vacíos de información. No había constancia de materiales del siglo IV a.C. en algunos poblados talayóticos (Primera Edad del Hierro), habitados hasta la época romana republicana o incluso el Alto Imperio. En sendas visitas de los autores a los de Els Antigors y Es Pedregar se localizaron dos individuos de T-8.1.1.1. en cada yacimiento.

En la imagen que resulta puede apreciarse una concentración de yacimientos de primer orden en el sur y suroeste de la isla (Fig. 6).

La topografía de acantilados alrededor de la zona del cabo Blanc limita el abastecimiento directo del grupo suroeste a Cala $\mathrm{Pi}$, pequeña cala localizada al final del torrente homónimo. En el extremo oriental de esta área, la línea de costa es mucho más baja (entre S'Estanyol y Sa Ràpita) y la descarga sería factible en diferentes puntos que podrían haber sido usados ocasionalmente, a pesar de la falta de hallazgos arqueológicos. No obstante, el grupo suroeste parece ser subsidiario del grupo sur. Aquí hay más lugares donde la descarga de productos sería más fácil como las playas de Es Trenc, Es Dolç, Es Carbó y Es Caragol y, en la zona al Este del cabo Salinas, también Cala Mármols al extremo del torrente del mismo nombre y Cala s'Almonia. De hecho, las zonas con mayor concentración de ánforas T-8.1.1.1. provenientes de prospección son las de Es Trenc y el triángulo formado por la Punta des Baus, Sa Talaia Grossa y Es Rafal des Porcs/Es Favassos, localizados a menos de $2 \mathrm{~km}$. de Cala Màrmols y Cala s'Almonia.

Desde estas áreas receptoras, se organizaría la distribución hacia el centro de la isla. La dispersión de las ánforas presenta una "lengua de vino" hacia el interior desde la costa (Fig. 2), que aún es más clara con respecto al vino ebusitano del siglo III a.C. (Fig. 5). El mapa señala una debilidad numérica de asentamientos de primer orden entre el potente grupo del suroeste y el grupo del Pla de Mallorca. No parece, pues, sostenible un modelo de poblado a poblado contiguo inmediato, sino una redistribución directa entre el grupo suroeste y el central. La distancia entre los grupos sur y

Trab. Prehist., 70, N. ${ }^{\circ}$ 2, julio-diciembre 2013, pp. 315-331, ISSN: 0082-5638

doi: $10.3989 /$ tp. 2013.12115 


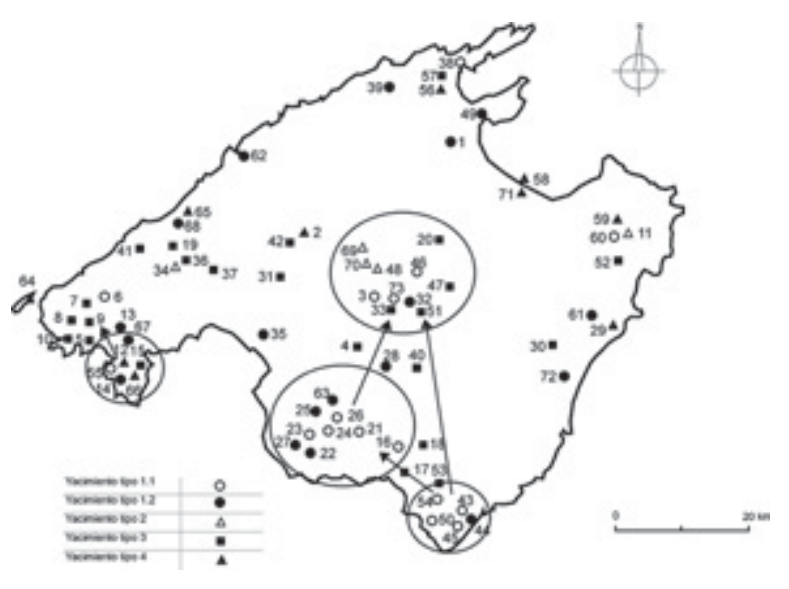

Fig. 6. Rutas de penetración y de recepción y redistribución entre núcleos. Tipología de los yacimientos: Asentamientos con murallas (1.1.) y sin ellas (1.2.); talayots aislados (2); estructuras con funciones indefinidas y yacimientos sin estructuras en superficie (3), Cuevas/ santuarios/ túmulos aislados (4): 1. Ca Na Bàssera, 2. Son PerotEs Bosquets, 3. Can Verd, 4. Son Veny, 5. Son Fortuny, 6. S'Alqueria, 7. S'Olivar Vell, 8. Camí de Morella, 9. Pla de Son Forners, 10. Sa Vinya des Metge, 11. Son Catiu, 12. Es Fornets, 13. Sa Torrota, 14. Ses Penyes Rotges, 15. Sa Vinya-Son Sastre, 16. Son Perot, 17. Sa Barrala, 18. S'Alqueria Fosca, 19. Es Bosquet, 20. Son Gil de Dalt, 21. Sa Talaia, 22. Capocorb Vell, 23. Gomera, 24. Can Moger, 25. Cas Frares, 26. Es Pedregar, 27. S'Àguila d'en Quart, 28. Es Figueral, 29. Sa Gruta, 30. Taiet, 31. Es Puig Blanc, 32. Puig des Moros, 33. Galiana, 34. Sarrià, 35. Son Oms Vell, 36. Sa Sínia, 37. Cas Jai, 38. Bóquer, 39. Pedruixella, 40. Sa Figuerassa, 41. Son Balaguer, 42. Can Moragues, 43. Rafal des Porcs-Es Balç, 44. Rafal des Porcs-Es Favassos, 45. Sa Talaia Grossa, 46. Es Meià, 47. Son Baró, 48. Binifat, 49. Pollentia, 50. Sa Vinya, 51. Putxet d'en Font, 52. Es Picó, 53. Rafal Llinàs-Na Mera Petita, 54. Antigors, 55. Puig de sa Morisca, 56. Sa Punta, 57. Gotmar, 58. Illa des Porros, 59. Sa Cova, 60. Ses Païsses, 61. Son Carrió, 62. Puig d'en Canals, 63. Son Taixaquet, 64. Cova des Moro o de sa Font (Dragonera), 65. Son Mas, 66. Son Ferrer, 67. Turó de Ses Beies, 68. Son Ferrandell, 69. Son Fred, 70. Cascanar, 71. Punta des Patró, 72. S’Hospitalet Vell, 73. Son Fornés.

suroeste con respecto al central está en torno a los 35 y $25 \mathrm{~km}$, respectivamente. Esta distancia es perfectamente accesible por animales de tiro guiados por los intermediarios. Una jornada a pie ha sido calculada para contextos prehistóricos en unos 27-32 km (Ruiz-Gálvez 1992: 96).

Un simple ejercicio permite calcular la densidad teórica del fenómeno. Entre 1975 y 1988, se había excavado un $10 \%$ del poblado de Son
Fornés, recuperándose 26 individuos de ánfora T-8.1.1.1. Ello significa que, si la distribución fuese uniforme, en el yacimiento tendríamos un NMI de 260 ánforas. Atendiendo a la fabricación de este tipo durante 100 años, la tasa de llegada al poblado sería de 2,6 recipientes por año. Con estas cifras, aún siendo teóricas, no podría hablarse de un comercio cuantitativamente relevante, de manera que el transporte tampoco habría constituido un problema para los autóctonos o foráneos encargados de la redistribución de vino a los poblados del interior. Incluso si no se hubiera producido en un episodio periódico, sino concentrado en momentos especiales (como las levas de mercenarios u otros), estas distancias tampoco habrían constituido un impedimento.

A modo de conclusión, y para responder a la pregunta que planteábamos al principio, podemos afirmar que no se produjo el cambio hacia un modelo de comercio maqom o empórico. El uso de un concepto como colonización parece totalmente inapropiado para describir la actividad ebusitana en Mallorca. Ningún lugar en el archipiélago balear puede ser considerado como una colonia, ni las dinámicas comerciales modificaron su naturaleza (únicamente en términos cuantitativos), al menos hasta el siglo II a.C., tras el drástico cambio del escenario internacional en el Mediterráneo Occidental.

Para el período analizado, se observa una transformación en la segunda mitad del siglo $\mathrm{V}$ a.C. con respecto a las dinámicas comerciales previas (Hernández-Gasch 2009). El vino empieza a penetrar en el interior por primera vez (Fig. 2) (10), aunque las comunidades que vivían junto a la costa retuvieron mayores cantidades de vino y toda la vajilla fina importada (Fig. 3). En el siglo IV a.C. se incrementa la cobertura territorial y cantidad de productos importados, aunque los asentamientos costeros mantienen una mayor proporción de ánforas (Fig. 4), como muestran las cifras corregidas de NMI por superficies excavadas. La vajilla de lujo y las ánforas de orígenes

(10) Teniendo en cuenta esta evidencia, las figuras de bronce datadas a finales del siglo VI a.C. o en la primera mitad del $\mathrm{V}$ a.C. recuperadas en el centro de Mallorca sin ningún método científico podrían haber llegado a asentamientos costeros de Mallorca y haber viajado dentro de la propia isla hacia sus destinos finales en períodos posteriores. En cualquier caso, su introducción en la isla es coherente con los contactos del período tardoarcaico (Hernández-Gasch 2009: 276). 
menos comunes permanecieron también en los núcleos cercanos a la costa. A su vez, y según los contextos arqueológicos del siglo IV a.C., la cerámica común ebusitana llegó a los poblados del centro de Mallorca junto con las propias ánforas de 'YBŜM'/Ebusus. Por ello, cabe insistir en que, aún siendo el vino el producto de importación predominante en Mallorca durante todo el período estudiado, la cerámica fina parece ser un elemento diacrítico entre las comunidades de la costa y las del interior, junto con la cantidad de vino recibida.

Por otra parte, se hace evidente que hay más de una realidad política autóctona. Las comunidades costeras, cuyo contacto directo con los ebusitanos es incuestionable, pudieron solicitar productos más distinguidos, como el vino y la vajilla de lujo, de otros lugares. Estos productos podrían haber sido usados por ciertos individuos o grupos para competir en una sociedad cada vez más compleja y jerarquizada, que empezó a armar y a enviar a hombres jóvenes al extranjero como mercenarios. Las comunidades del interior, por su parte, probablemente carentes de un contacto directo con gentes foráneas y menos expuestas a estímulos culturales externos, no demandaron de la misma manera productos de lujo. Las importaciones redistribuidas hacia los asentamientos del interior estaban muy posiblemente en manos de los grupos de la costa, como sugieren la cantidad y variedad de los productos, junto con la categorización de yacimientos (Fig. 6). Las comunidades que vivían en el suroeste de Mallorca y, en especial, en su extremo sur, donde la densidad de asentamientos, su tamaño y su apariencia monumental parece mayor, seguramente jugaron un papel notable en la redistribución de productos hacia el Pla de Mallorca. El que la base ebusitana del islote de $\mathrm{Na}$ Guardis actuara como lugar de apoyo no parece una condición indispensable para explicar ese alto grado de concentración en el triángulo conformado entre el cabo Salinas, la Punta des Baus y la playa de Es Trenc, ya que desde Eivissa hasta ellos probablemente hay una jornada de navegación o poco más. Los hallazgos en el Este de la isla, las bahías del norte o en la Sierra de Tramuntana no pueden relacionarse con las actividades llevadas a cabo en asentamientos como $\mathrm{Na}$ Guardis o Puig de sa Morisca, aunque sí con las de los comerciantes ebusitanos que podían servirles directamente.

Se ha sugerido en algunas ocasiones el intercambio de productos de lujo por ganado o carne salada. Sin embargo, parece poco probable que una economía mixta sin signos de especialización hubiese podido producir tales excedentes (Hernández-Gasch et al. 2002; Hernández-Gasch et al. 2011). Tampoco cabe pensar en excedentes agrarios, dado que los silos prehistóricos son infrecuente en Mallorca, en contraposición con su alta frecuencia en el área catalana durante el período ibérico e incluso previo (Asensio et al. 2002). En el taller metalúrgico de $\mathrm{Na}$ Guardis se trabajaba el hierro, pero las evidencias de recogida de material en Mallorca por parte de los ebusitanos son más que escasas, incluso en períodos posteriores (Guerrero 1989). También se ha atribuido a los ebusitanos un interés comercial por las salinas pero los campamentos de explotación de la sal funcionaron en su mayoría entre los siglos I y III d.C. Como diferentes autores han apuntado, parece que los mercenarios fueron el intercambio más importante con el mundo púnico.

La progresiva impregnación del vino en la isla, junto a otros productos menores, claramente aparece como un fenómeno conectado con agentes foráneos en las comunidades costeras, a las que siguen más tarde las del interior. La dinámica pudo empezar en el siglo VI a.C., explorando de manera gradual los recursos disponibles. Se vio fortalecida en el siglo IV a.C. con el considerable aumento de la cantidad de vino y del número de comunidades involucradas en la red de intercambio. La necesidad de mercenarios combinada con la de vino de las élites locales fueron probablemente responsables de ello.

En la Península Ibérica, las grandes cantidades de ánforas han sido vinculadas con sociedades complejas en proceso de diferenciación jerárquica (Sanmartí 2005; Sanmartí et al. 2009). Mientras que este proceso en el área catalana es apreciable por las notables cantidades de ánfora T-1.3.2.3. y por la exportación de cereales almacenados en silos en determinados puntos del territorio, en las islas Baleares el intercambio se llevó esencialmente a cabo en el siglo IV, cuando los cartagineses luchaban contra las polis griegas en Sicilia. Se ha argumentado, en el caso ibérico, que las importaciones eran distribuidas por las élites emergentes en banquetes y fiestas comunales para conseguir prestigio y el apoyo de la población. Un fenómeno similar pudo haberse dado en las islas Baleares durante la Segunda Edad del Hierro, a la vez que dicha élites han sido detectadas en algunas necró-

Trab. Prehist., 70, N. ${ }^{\circ}$ 2, julio-diciembre 2013, pp. 315-331, ISSN: 0082-5638

doi: $10.3989 /$ tp.2013.12115 
polis (Hernández-Gasch 1998). Estas élites serían las responsables en mayor grado de la construcción de las murallas de los poblados y los santuarios (Hernández-Gasch 2009), junto con la organización y fomento del reclutamiento de mercenarios. Así pues, la difusión de la cultura del vino podría haberse diseñado como una estrategia para ganarse el favor de la población alrededor de empresas peligrosas, como fueron las guerras lejos de la isla.

\section{AGRADECIMIENTOS}

El Dr. Víctor M. Guerrero y el Dr. Manel Calvo nos permitieron la publicación de cerámicas inéditas del Puig de sa Morisca y el Túmul de Son Ferrer. Guy de Mulder y Magdalena Salas nos proporcionaron información sobre los materiales de Son Ferrandell y S'Hospitalet Vell, respectivamente.

\section{BIBLIOGRAFÍA}

Alvar, J. 1999: "Los fenicios en Occidente". En J. M. Blázquez, J. Alvar y C. G. Wagner (eds.): Fenicios y cartagineses en el Mediterráneo, Cátedra, Madrid: 313-447.

Amin, S. 1975: El desarrollo desigual. Fontanella. Barcelona.

Amin, S. 1976: Imperialismo y desarrollo desigual. Fontanella. Barcelona.

Aramburu-Zabala, J. 2004: Mallorca arqueològic. Contribució a l'inventari de jaciments. Consell Insular de Mallorca. Palma. CD-ROM.

Aramburu-Zabala, J. 2009: Ses Païsses (Artà, Mallorca). Excavaciones en el edificio 25 ('Climent Garau'). http://www.arqueobalear.es (consulta 12-I-2012).

Aramburu-Zabala, J. y Hernández-Gasch, J. 2005: Ses Païsses, 1999-2000. http://www.arqueobalear. es/articulos/Excavaciones_SP99-00.pdf (consulta 14-I-2012).

Arribas, A.; Trias, M. G.; Cerdà, D. y Hoz, J. de 1987: El barco de El Sec (Calvià, Mallorca). Ajuntament de Calvià - Universitat de les Illes Balears. Palma.

Arruda, A. M. 2000: Los fenicios en Portugal. Fenicios y mundo indígena en el centro y sur de Portugal (siglos VIII-VI a.C.). Cuadernos de Arqueología Mediterránea 5-6, Universitat Pompeu Fabra. Barcelona.

Asensio, D.; Francès, J. and Pons, E. 2002: "Les implicacions econòmiques i socials de la concentració de reserves de cereals a la Catalunya costanera en época ibérica”. Cypsela 14: 125-140.
Aubet, M. E. 1994: Tiro y las colonias fenicias de Occidente. Crítica. Barcelona.

Blázquez, J. M. 1999: "Los fenicios en Oriente". En J. M. Blázquez, J. Alvar y C. G. Wagner (eds.): $\mathrm{Fe}$ nicios y cartagineses en el Mediterráneo. Cátedra. Madrid: 11-310.

Blázquez, J. M. 2007: "Últimas aportaciones a la presencia de fenicios y cartagineses en Occidente". Gerión 25 (2): 9-70.

Calvo, M.; Quintana, C. y Guerrero, V. 2009: “Territori i intercanvi: la influencia púnica en la comunitat talaiòtica del Puig de sa Morisca (Calvià)". I ${ }^{a}$ Trobada d'arqueòlegs de les Illes Balears (Manacor 2006): 63-72. Palma.

Cardell, J.; Cau, M.A. y Orfila, M. 1994: "La prehistoria". En G. Alomar, J. Cardell, M. A. Cau y M. Orfila (eds.): Història de Muro I. De la Prehistòria fins al 1229. Ajuntament de Muro. Mallorca: 21-128.

Cerdà, D. 2002: Bocchoris. El món clàssic a la badia de Pollença. Consell de Mallorca. Palma.

Coll, J. 1989: La evolución del ritual funerario en la Cultura Talaiòtica. Tesis doctoral, microficha 19, Universitat de les Illes Balears. Palma.

Delgado, A. 2008: “Colonialismos' fenicios en el sur de Iberia: historias precedentes y modos de contacto". En G. Cano y A. Delgado (eds.): De Tartessos a Manila. Siete estudios coloniales y postcoloniales. Universitat de València. València: 19-49.

De Mulder, G.; Deschieter, J. y Van Strydonck, M. 2007: "La céramique romaine du site cultuel de Son Mas (Majorque, Espagne)". En Actes du Congrès de la Société Française d'Étude de la Céramique Antique de Gaule (Langres 2007): 353-366. Marseille.

Dietler, M. 2009: "Colonial encounters in Iberia and the Western Mediterranean: An exploratory framework". En M. Dietler y C. López-Ruiz (eds.): Colonial encounters in Ancient Iberia. Phoenician, Greeks and Indigenous relations. University Chicago Press. Chicago: 3-48.

Dietler, M. 2010: “Cocina y colonialismo. Encuentros culinarios en la Francia mediterránea protohistórica”. En C. Mata, G. Pérez Jordà y J. Vives-Ferrándiz (eds.): De la cuina a la taula. IV Reunió d'economia en el Primer Mil-lenni a.C. Saguntum extra 9, Universitat de València. València: 11-26.

Diodoro de Sicilia: Bibliotheca Historica, traducción y notas de J. J. Torres Esbarranch (2004), Gredos, Madrid.

Fernández, J. H. y Costa, B. 2004: “Mundo funerario y sociedad en la Eivissa arcaica. Una aproximación al anàlisis de los enterramientos de cremación en la necrópolis del Puig des Molins". En A. González Prats (ed.): El mundo funerario. Actas del III Seminario Internacional sobre Temas Fenicios (Guadamar del Segura 2002): 315-408. Alacant.

Fernández, J. H. y Granados, J. O. 1980: Cerámica de imitación ática en el Museo Arqueológico de Ibiza. Trabajos del Museo Arqueológico de Ibiza 2. Eivissa. 
Gómez de Caso, J. 2005: "El ejército cartaginés en la primera guerra púnica". En B. Costa y J. H. Fernández (eds.): Guerra y ejército en el mundo fenicio-púnico, XIX Jornadas de Arqueología Fenicio-Púnica (Eivissa 2004). Treballs del Museu Arqueològic d'Eivissa i Formentera 56, Museu Arqueològic d'Eivissa. Eivissa.

González de Canales, F.; Serrano, L. y Llompart, J. 2008: "Tarsis y la monarquía unificada de Israel". Gerión 26 (1): 61-88.

Gornés, S.; Gual, J. y López, A. 1992: "Hipogeos talaióticos del hierro en Menorca: un problema de cambio $\mathrm{y} / \mathrm{o}$ respuesta cultural frente a los primeros contactos coloniales". Revista de arqueología 131: 12-21.

Gosden, C. 2004: Archaeology and Colonialism. Cultural Contact from 5000 BC to Present. Cambridge University Press. Cambridge.

Guerrero, V. 1981: Los asentamientos humanos sobre los islotes costeros de Mallorca. Trabajos del Museo de Mallorca 31, Dirección General de Bellas Artes Archivos y Bibliotecas. Madrid.

Guerrero, V. 1984a: El asentamiento púnico de Na Guardis. Excavaciones Arqueológicas en España 133, Ministerio de Cultura. Madrid.

Guerrero, V. 1984b: La colonización púnico ebusitana de Mallorca. Estado de la cuestión. Trabajos del Museo Arqueológico de Ibiza 11, Museo Arqueológico de Ibiza. Eivissa.

Guerrero, V. 1987: La Colònia de Sant Jordi (Mallorca). Estudis d'arqueologia i epigrafía. Publicacions del Centre d'Estudis "Gabriel Alomar". Palma.

Guerrero, V. 1989: "Puntos de escala y embarcaderos púnicos en Mallorca: Illot d'en Sales". Butlletí de la Societat Arqueològica Lul-liana 45: 27-38.

Guerrero, V. 1997: La colonización púnica de Mallorca. La documentación arqueológica y el contexto histórico. El Tall. Palma.

Guerrero, V. 1999: La cerámica protohistórica a torno de Mallorca (s. VI-I a.C.). British Archaeological Reports, International Series 770, Archaeopress. Oxford.

Guerrero, V. 2004: "Colonos e indígenas en las Baleares prerromanas". Colonialismo e interacción cultural: el impacto fenicio púnico en las sociedades autóctonas de occidente. XVIII Jornadas de arqueología fenicio-púnica (Eivissa 2003). Treballs del Museu Arqueològic d'Eivissa i Formentera 54, Museu Arqueològic d'Eivissa i Formentera. Eivissa: 145-203.

Guerrero, V.; Calvo, M. y Salvà, B. 2002: "La cultura talayótica. Una sociedad de la Edad del Hierro en la periferia de la colonización fenicia”. Complutum 13: 221-258.

Hernández-Gasch, J. 1998: Son Real. Necrópolis talayótica de la edad del hierro. Estudio arqueológico $y$ análisis social. Arqueo Mediterrània 3 (II), Universitat de Barcelona. Barcelona.

Hernández-Gasch, J. 2009: "Les Illes Balears en época tardoarcaica". En X. Nieto y M. Santos: El vaixell grec arcaic de Cala Sant Vicenç. Monografies del CASC 7, Museu d'Arqueologia de CatalunyaCentre d'Arqueologia Subaquàtica de Catalunya. Girona: 273-292.

Hernández-Gasch, J.; Nadal, J.; Malgosa, A.; Alesán, A. y Juan, J. 2002: "Economic strategies and limited resources in the Balearic insular ecosystem: the myth of an indigenous animal farming society in the First Millennium BC". En W. H. Waldren y J. A. Ensenyat (eds.): World Islands in Prehistory. International Insular Investigations. V Deià Conference of Prehistory (2001). British Archaeological Reports, International Series 1095, Archaeopress. Oxford: 275-291.

Hernández-Gasch, J.; Ramis, D. y Rosselló, J. A. 2011: "Economia, societat i canvi cultural a les Gimnèsies. La interpretació de les dades bioarqueològiques a les Illes Balears en el primer mil·lenni a.n.e.”. En S. Valenzuela-Lamas, N. Padrós, M. C. Belarte y J. Sanmartí (eds.): Economia agropecuària i canvi social a partir de les restes bioarqueològiques. El primer mil-lenni aC a la Mediterrània occidental. Actes de la V Reunió Internacional d'Arqueologia de Calafell (2009). Arqueo Mediterrània 12, Universitat de Barcelona. Barcelona: 123-138.

Krueger, M. 2008: "Valor, prestigio e intercambio. Los métodos ante la teoría". Herakleion 1: 7-19.

Lamboglia, N. 1952: "Per una classificazione preliminare della ceramica campana", Actes du I Congres Int. d'Études Ligures, Mónaco, Bordighera, Gềnes (1950), Bordighera:139-206.

López Castro, J. L. 2000: "Formas de intercambio de los fenicios occidentales en época arcaica". En P. Fernández Uriel, C. G. Wagner y F. López Pardo (eds.): Intercambio y comercio preclásico en el Mediterráneo. Actas I coloquio del Centro de Estudios Fenicios y Púnicos (Madrid 1998): 123-136. Madrid.

López Castro, J. L. 2008: "El poblamiento rural fenicio en el sur de la Península Ibérica entre los siglos VI a III a.C.". Gerión 26 (1): 149-182.

López Garí, J. M. y Marlasca Martín, R. 2012: “Les rasses de conreu d'època antiga $i$ el patrimoni històric arqueològic a Eivissa: un repte urgent". En M. Riera Rullán (ed.): IV Jornades d'Arqueologia de les Illes Balears (Eivissa 2010): 155-122. Palma.

Lull, V.; Micó, R.; Rihuete, C. y Risch, R. 1999: La Cova des Càrritx y la Cova des Mussol. Ideología y sociedad en la prehistoria de Menorca. Consell Insular de Menorca. Ciutadella.

Lull, V.; Micó, R.; Rihuete, C. y Risch, R. 2001: La prehistòria de les Illes Balears i el jaciment de Son Fornés (Montuïri, Mallorca). Fundació Son Fornés. Montuïri.

Mascaró Pasarius, J. 1961-67: Corpus de toponimia de Mallorca. Gráficas Miramar. Palma.

Mascaró Pasarius, J. 1967: Monumentos prehistóricos y protohistóricos de la Isla de Mallorca. Gráficas Miramar. Palma.

Trab. Prehist., 70, N. ${ }^{\circ}$ 2, julio-diciembre 2013, pp. 315-331, ISSN: 0082-5638

doi: $10.3989 /$ tp.2013.12115 
Mascaró Pasarius, J. 1968: Prehistoria de las Baleares. Gráficas Miramar. Palma.

Mayoral, F. 1984: "La fase Postalayótica mallorquina: periodización y dinámica económico-social". En W. Waldren, R. Chapman, J. Lewthwaite y K. Rex-Claire (eds.): Early settlement in the Western Mediterranean Islands and their Peripherial Areas. British Archaeological Reports, International Series 229 (IV), Archaeopress. Oxford: 1299-1313.

Mederos, A. 2006: "Fenicios en Huelva, en el siglo X a.C, durante el reinado de Hiram I de Tiro". SPAL 15: $167-188$.

Moreno Arrastio, F. J. 2008: "En El Corazón de las Tinieblas. Forma y dinámica de la colonización fenicia de Occidente". Gerión 26-1: 35-60.

Morey, A. 2009: "La gran albufera de Mallorca. Formas de explotación y conflictividad ambiental (siglos XVI-XX)". Butlletí de la Societat Arqueològica Lul.liana 69: 219-240.

Palomar, B. 2005: La ceràmica posttalaiótica de Mallorca. Significació econòmica i social dels canvis en el procés productiu entre c. 450-250 cal ANE: El cas de Son Fornés, Montuïri. Tesi doctoral. Universitat Autònoma de Barcelona. http://www.tesisenxarxa.net/TDX-0221107-122929/\#documents (consulta 15-I-2012).

Quintana, C. 2000: La ceràmica superficial d'importació del Puig de sa Morisca. Ajuntament de Calvià. Calvià.

Quintana, C. 2005: "El conjunt amfòric del poblat de Ses Païsses, segles V a.C. - I/II d.C." En J. Aramburu-Zabalay y J. Hernández-Gasch: Ses Païsses, 1999-2000. Internet Edition: http://www.arqueobalear.es/articulos/Excavaciones_ SP99-00.pdf (consulta 12-I-2012).

Quintana, C. y Guerrero, V. 2004: "Las ánforas del Puig de sa Morisca. Los contextos del siglo IV a.C.". En J. Sanmartí, D. Ugolini, J. Ramon y D. Asensio (eds.): La circulació d'àmfores al Mediterrani occidental durant la Protohistòria (segles VIII-III $a C)$ : aspectes quantitatius $i$ anàlisi de continguts. Arqueo Mediterrània 8, Universitat de Barcelona. Barcelona: 253-260.

Ramon, J. 1991: Las ánforas púnicas de Ibiza, Trabajos del Museo Arqueológico de Ibiza 23. Museo Arqueológico de Ibiza. Eivissa.

Ramon, J. 1995: Las ánforas fenicio-púnicas del Mediterráneo central y occidental. Col-lecció Instrumenta 2, Universitat de Barcelona. Barcelona.

Ramon, J. 2005: "Eivissa fenicio-púnica, 25 anys d'investigació". Fonaments 12: 107-138.

Ramon, J. 2007: Excavaciones arqueológicas en el asentamiento fenicio de sa Caleta. Cuadernos de Arqueología Mediterránea 16, Universitat Pompeu Fabra. Barcelona.

Rosselló i Verger, V. M. 2000: "El Prat de Sant Jordi (Mallorca) i la seva dessecació". Treballs de la Societat Catalana de Geografia XV, 50: 119-139.
Ruiz-Gálvez, M. 1992: “Orientaciones teóricas sobre intercambio y comercio en Prehistoria". Gala 1: $87-101$

Ruiz-Gálvez, M. 1998: La Europa atlántica en la Edad del Bronce. Un viaje a las raices de la Europa occidental. Crítica. Barcelona.

Salvà, B. y Hernández-Gasch, J. 2009: "Els espais domèstics a les Illes Balears durant les edats del bronze i del ferro. De la societat Naviforme a la Talaiòtica". En M. C. Belarte (ed.): L'espai domèstic i l'organització de la societat a la protohistòria de la Mediterrània occidental (Ier mil·lenni $a C$ ). Actes de la IV Reunió Internacional d'Arqueologia de Calafell (Calafell-Tarragona 2007). Arqueo Mediterrània 11, Universitat de Barcelona. Barcelona: 299-330.

Sanmartí, J. 2005: "La conformación del mundo ibérico septentrional". Actas del IX Coloquio sobre lenguas y culturas paleohispánicas (Barcelona 2004). Paleohispánica 5: 333-358.

Sanmartí, J.; Asensio, D.; Belarte, M. C. y Noguera, J. 2009: "Comerç colonial, comensalitat i canvi social a la protohistòria de Catalunya". En J. Diloli y S. Sardà (eds.): Ideologia, pràctiques rituals $i$ banquet al nord-est de la península Ibèrica durant la Protohistòria. Citerior 5, Arola Editors. Tarragona: 219-238.

Sanmartí, J.; Hernández-Gasch, J. y Salas, M. 2002: "El comerç protohistòric al nord de l'illa de Mallorca". Cypsela 14: 107-124.

Sparkes, B. y Talcott, L. 1970: Black and plain pottery of the 6th, 5th and 4th centuries B.C. The Atenian Agora XII, American School of Classical Studies at Athens.Princeton.

Thomas-Vallon, C. y Vallon de Montgrand, A. 2006: Lucullus dine chez Lucullus: cuisine antique grecque et romaine. Éditions Équinoxie. Saint-Rémyde-Provenze.

Vallespir, A.; Prohens, J. M.; Orfila, M. y Merino, J. 1987: "Los yacimientos de Santa Ponça (Calvià)". Mayurqa 21: 1-30.

Van Dommelen, P. 1998: On colonial grounds. A comparative study of colonialism and rural settlement in first millennium $B C$ west central Sardinia. Archaeological Studies Leiden University 2. Leiden University. Leiden.

Vives-Ferrándiz, J. 2005: Negociando encuentros. Situaciones coloniales e intercambios en la costaoriental de la península Ibérica (siglos VIII-VI a.C.). Quaderns d'Arqueologia Mediterrània 12, Universitat Pompeu Fabra. Barcelona.

Wagner, C. G. 1993: "Aspectos socioeconómicos de la expansión fenicia en Occidente: El intercambio desigual y la colonización agrícola". Revista d'Estudis d'Història Econòmica 1: 1-37.

Wagner, C. G. 2008: "Tiro, Melkart, Gadir y la conquista simbólica de los confines del mundo". En R. González Anton, F. López Pardo y V. Peña (eds.): Los fenicios y el Atlántico. Centro de Estudios Fenicios y Púnicos. Madrid: 11-29. 